\title{
Yochelcionellids from the Early and Late Cambrian of North Greenland
}

\author{
John S. Peel \\ Grønlands Geologiske Undersøgelse, Øster Voldgade 10, DK-1350 København K, Danmark.
}

Yochelcionellids are small, slightly coiled, cap-shaped problematic molluscs characterised by a prominent tube, the snorkel, which emerges from the shell wall below the apex. They were originally described from the Middle Cambrian of Australia (Runnegar \& Pojeta, 1974; Runnegar \& Jell, 1976, 1980) and were assigned to the Class Monoplacophora, together with the often similarly coiled, but snorkel-lacking, helcionellids. Yochelcionella has subsequently been described from the Early Cambrian of Pennsylvania, U.S.A., by Runnegar \& Pojeta (1980).

Yochelcionellids of Late Cambrian (Dresbachian) age were collected in the Cass Fjord Formation of Washington Land, western North Greenland, during 1975. In 1979 and 1980 specimens of late Early Cambrian age (Bonnia-Olenellus Zone) were collected from two as yet un-named formations of the Brønlund Fjord Group (Ineson \& Peel, 1980). The most complete specimen from Peary Land exhibits the laterally compressed form typical of Yochelcionella americana Runnegar \& Pojeta, 1980, although the conch is high and slowly expanding, as in Y. ostentata Runnegar \& Jell, 1976, a Middle Cambrian species. The Dresbachian specimens from Washington Land resemble $Y$. cyrano and $Y$. daleki, Middle Cambrian species described by Runnegar \& Jell (1976) from Australia, in terms of conch morphology, although the snorkel appears to show the connection with the aperture held to be characteristic of Eotebenna Runnegar \& Jell, 1976.

\section{References}

Ineson, J. R. \& Peel, J. S. 1980: Cambrian stratigraphy in Peary Land, eastern North Greenland. Rapp. Grønlands geol. Unders. 99, 33-42.

Runnegar, B. \& Jell, P. A. 1976: Australian Middle Cambrian molluscs and their bearing on early molluscan evolution. Alcheringa 1, 109-138.

Runnegar, B. \& Jell, P. A. 1980: Australian Middle Cambrian molluscs: corrections and additions. Alcheringa 4, 111-113.

Runnegar, B. \& Pojeta, J. 1974: Molluscan phylogeny: The paleontological viewpoint. Science 186, 311-317.

Runnegar, B. \& Pojeta, J. 1980: The monoplacophoran mollusk Yochelcionella identified from the Lower Cambrian of Pennsylvania. J. Paleont. 54, 635-636. 